\title{
Effect of filaments diameter on the mechanical properties of wrap hybrid CFRP
}

DOI: $10.35530 / I T .072 .02 .1733$

\section{ABSTRACT - REZUMAT \\ Effect of filaments diameter on the mechanical properties of wrap hybrid CFRP}

In this paper, the vine-like structure of carbon bundles was designed through polyester fibre wrapping for better mechanical properties. The effect of wrapped hybrid structure and diameters of polyester fibre on the mechanical properties of carbon-polyester fibre/epoxy unidirectional composites was investigated experimentally. Five kinds of specimens with different polyester filament diameters were produced. The impact, tensile and unidirectional compressive properties of WHC (Wrap Hybrid Composite) were measured. Experimental results show that: it can be developed with strength and toughness properties far superior to those of their constituents, the compressive fracture morphology of specimens indicated that the fracture patterns of composites depend on wrapped hybrid structure, polyester fibres with higher tensile strengths provide better impact resistance, while thinner wrapping fibres enhance the compression properties of the composite material more effectively. The diameter of the wrapping fibre should be optimized as per the application of the composite material. The vine-like structure can provide a new design method for the structural design of continue fibre reinforced composite materials.

Keywords: fibre reinforced polymer, wrapped hybrid, compression failure, impact energy

\section{Influența diametrului filamentelor asupra proprietăților mecanice ale CFRP hibrid înfășurat}

În această lucrare, structura asemănătoare viței-de-vie a fasciculelor de carbon a fost proiectată prin înfășurarea fibrei de poliester pentru proprietăți mecanice superioare. Influența structurii hibride înfășurate și a diametrelor fibrelor de poliester asupra proprietăților mecanice ale compozitelor unidirecționale din fibră de carbon-poliester/epoxidice a fost investigată experimental. Au fost produse cinci tipuri de probe cu diferite diametre de filament de poliester. Au fost deteminate rezistența la impact, rezistența la tracțiune și proprietățile de compresie unidirecționale ale WHC (Wrap Hybrid Composite - compozit hibrid înfășurat). Rezultatele experimentale arată că: poate fi dezvoltat cu proprietăți de rezistență mult superioare constituenților lor, morfologia compresivă a specimenelor a indicat faptul că modelele de formare ale compozitelor depind de structura hibridă înfășurată, fibrele de poliester cu rezistențe la tracțiune mai ridicate oferă o rezistență la impact superioară, în timp ce fibrele înfășurate mai subțiri sporesc mai eficient proprietățile de compresie ale materialului compozit. Diametrul fibrei înfășurate trebuie optimizat conform aplicației materialului compozit. Structura asemănătoare viței-de-vie poate oferi o nouă metodă de proiectare pentru proiectarea structurală a materialelor compozite armate cu fibre.

Cuvinte-cheie: polimer armat cu fibre, hibrid înfășurat, eșec de compresie, energie de impact

\section{INTRODUCTION}

Carbon fibre reinforced polymer composites (CFRP) have been widely used in aircraft and aerospace engineering industries for a long time due to their high specific strength to weight ratio and excellent corrosion resistance property, making it be ideal materials for designing on road and in air vehicles with less fuel consumption [1-4]. The design-ability of mechanical properties for CFRP is prominent due to it is an anisotropic composite material with a fibre arrangement structure. The reinforced fibres are usually papered as textile prefabs, such as plain weave, stitching, knitting, and three-dimensional textile structure. Apart from the textile structure design, the hybrid structure, which made of two different types of high strength fibre composed with the same resin matrix to meet specific strength requirements, has been recognized as an important design method for many engineering applications [5]. They are generally used to reduce the costs of composites that have a combination of the best mechanical, wear, thermal or other properties. Many studies have been done on the development of carbon nanotube reinforced composites. But there are many problems with the way these materials are produced, including the problems of irregularity and the accumulation of nanotubes in one place [6]. Belle and colleagues showed that by applying the chemical vapour deposition process, a smooth thin layer of carbon nanotubes can be created on the outer surface of the fibre optic. They showed that the mechanical and electrical properties 
of such a layer improved due to the growth of carbon nanotubes on the surface of alumina fibre.

Some researchers have investigated the hybrid composite with different hybrid structures. Hung et. al [7] have studied the impact response of layer hybrid carbon, glass or basalt fibre reinforced polymer composites to obtain a structure strong enough, relatively low-cost composite material. Zheng [8] co-braided hybrid structure on the tensile response of carbon/ aramid hybrid braided composites. The compromise optimization of strength and toughness can be achieved by carbon-aramid hybrid composites. Liu [9] investigated the erosion characteristics of hybrid fabric reinforced polyetherimide composite and proposed a new non-crimp hybrid structure for better mechanical properties and erosion resistance. The above hybridization is classified into interlaminate, laminate, which involves depositing layers composed of different fibres, and intraluminal, where different types of fibres are entangled within a single layer.

In our previous study, a vine-like structure fibre hybridization was proposed. Inspiration and sketches are shown in figure 1. Wrapping reinforced fibre bundle for high unidirectional compressive performance [10], polybenzoxazole (PBO) beers was used as the covered filament, which consists of rigid rod chain molecules, it has high tensile strength and a high modulus, the reinforced fibre bundle was ultra-high molecular weight polyethylene fibre. The vine-tree structure is widely observed in nature when the plant has a growth habit of trailing or climbing stems. The vines use trees for growth rather than devoting energy to development of supportive tissue, enabling the vine to reach sunlight with a minimum investment of energy. The trees may also facilitate the transportation of nutrient substances. Such hierarchical vinetree structures offer synergy between the vines and trees as well as the maximum utilization of sunshine and limited soil and space, which could also be a promising universal architecture in both macro- and micro-worlds. The experimental results showed that the wrap structure affects the compressive failure pattern, and then improve the compression strength and modulus of unidirectional composites.

In this paper, the effect of wrapping filament diameter on the compression, tension and impact properties of composite was investigated. Five types of polyester monofilament was used to wrap the carbon fibre bundle. Finally, the PET/CFRP wrapped hybrid composite was made by VARTM(vacuum assisted resin transfer moulding) with epoxy resin. The mechanic behaviour and failure mechanism of the material were analysed.

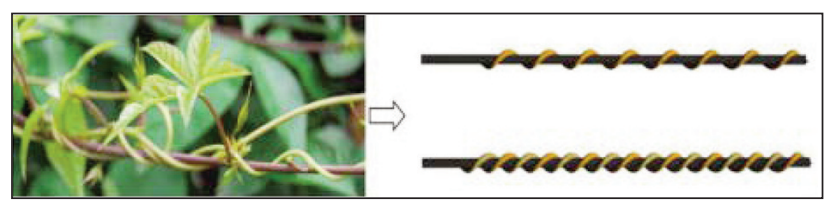

Fig. 1. Vine-like structure

\section{EXPERIMENTAL}

\section{Materials}

Carbon fibre was employed as reinforcing the material, which was purchased from Toray Co. Ltd. (Tokyo, Japan) with a tensile strength of $3530 \mathrm{MPa}$ and a tensile modulus of $230 \mathrm{GPa}$. There is 3000 single fibres in a bundle of carbon fibre (3K). The polyester filament was used as the wrapping fibres, it was offered by Bosidi new material Co., Ltd. (Dongguan, China). Polyester filaments was a kind of mono-filament, the shape of those sections was round, their diameter was $0.1 \mathrm{~mm}, 0.2 \mathrm{~mm}, 0.4 \mathrm{~mm}$ and $0.6 \mathrm{~mm}$. A thermosetting epoxy compound system was obtained from Jiafa Chem Co., Ltd. (Changshu, China). The mixture ration of epoxy resin(1.12-1.16 g/cm ${ }^{3}$ in density, $0.54-0.57 \mathrm{eq} / 100 \mathrm{~g}$ in Epoxy value, 175-185 in Epoxy equivalent, $2500 \mathrm{MPa} / \mathrm{s}$ in viscosity) and curing agent $\left(0.92-0.96 \mathrm{~g} / \mathrm{cm}^{3}\right.$ in density, $450-510$ $\mathrm{mg} \mathrm{KOH} / \mathrm{g}$ in amine value, $55-60 \mathrm{~g} / \mathrm{eq}$ in active hydrogen equivalent, 40-80 MPa/s in Viscosity) was 100:27 at ambient temperature.

\section{Preparation of WHC}

The Wrapped carbon fibre bundles with mono-filament Hybrid Composite (WHC) were prepared using a custom winding machine and VARTM method. Firstly, the PET filament was wrapped on a spool rather than having a sleeve on the hollow shaft. With the carbon bundle throughout the centre of the shaft, the PET filament wrapped the carbon fibre upon spool rotation. Then, a unidirectional fabric was prepared by a rotary arrangement method. Four layers were paved for a composite laminate, and composed with the epoxy resin used the VARTM process. A schematic diagram is shown in figure 2.

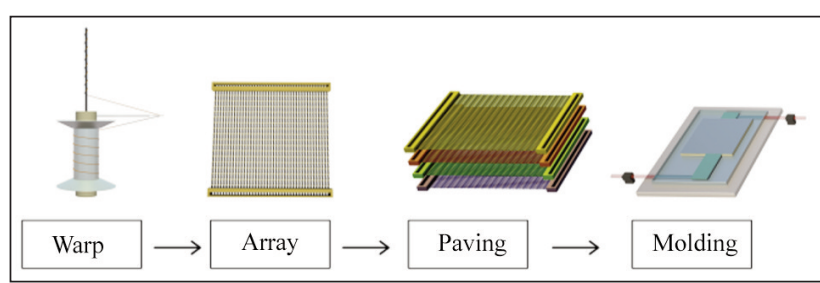

Fig. 2. Schematic of the preparation process for WHC

\section{Samples}

Five groups of samples were prepared, four kinds of PET mono-filaments with different diameters $(0.1 \mathrm{~mm}$,

\begin{tabular}{|c|c|c|}
\hline \multicolumn{3}{|c|}{ Table 1 } \\
\hline Sample & $\begin{array}{c}\text { Diameter of PET } \\
(\mathbf{m m})\end{array}$ & $\begin{array}{c}\text { Thickness } \\
(\mathbf{m m})\end{array}$ \\
\hline CFRP & - & 1.38 \\
\hline 0.1 P/CFRP & 0.1 & 1.65 \\
\hline 0.2 P/CFRP & 0.2 & 1.97 \\
\hline 0.4 P/CFRP & 0.4 & 3.68 \\
\hline $0.6 P / C F R P$ & 0.6 & 4.69 \\
\hline
\end{tabular}


$0.2 \mathrm{~mm}, 0.4 \mathrm{~mm}$ and $0.6 \mathrm{~mm}$ ) were used in wrap hybrid fibre, a group of no hybrid sample was prepared for comparison. All samples were prepared with the same effective fibre volume content (refers to carbon fibre volume content). The sample names and thickness listed in table 1.

\section{Measurement and characterization}

Impact test was performed by the Charpy impact test machine (XJJ-50S, HengSi Instruments Co., Ltd. China). Flat composite samples were placed in the middle of the test machine. Impactor had a smooth hemispherical striker with a diameter of $2 \mathrm{~mm}$. The falling height of the impactor was adjusted to the energy requested to the values of $7.5 \mathrm{~J}$. The energy absorbed and impact strength of the specimen was collected.

Compressive and tensile testing was carried out by a universal testing machine (WDW-20, $20 \mathrm{kN}$ load cell, made by Tianchen testing machine manufacturing Co., Ltd. China). Compression specimens were loaded until failure using a constant crosshead speed of $0.5 \mathrm{~mm}$ in -1 . In addition to compressive stress, strain data was also collected for each composite configuration with strain gauges ( $8 \mathrm{~mm}$ gauge length) being carefully installed at the mid-span of the test gauge lengths.

A crosshead speed of $2 \mathrm{~mm} / \mathrm{min}$ was used for the tensile test. Also, a single strain gauge was attached to the centre of the specimen in the longitudinal direction to measure the tensile strain.

\section{RESULTS AND DISCUSSION}

Figure 3 shows the effect of fibre diameter on the impact strength of the material. As can be seen from the figure 3, fibre wrapping improves the impact resistance of the composite material. Impact strength decreases as diameter increases and is highest for a diameter of $0.4 \mathrm{~mm}$.

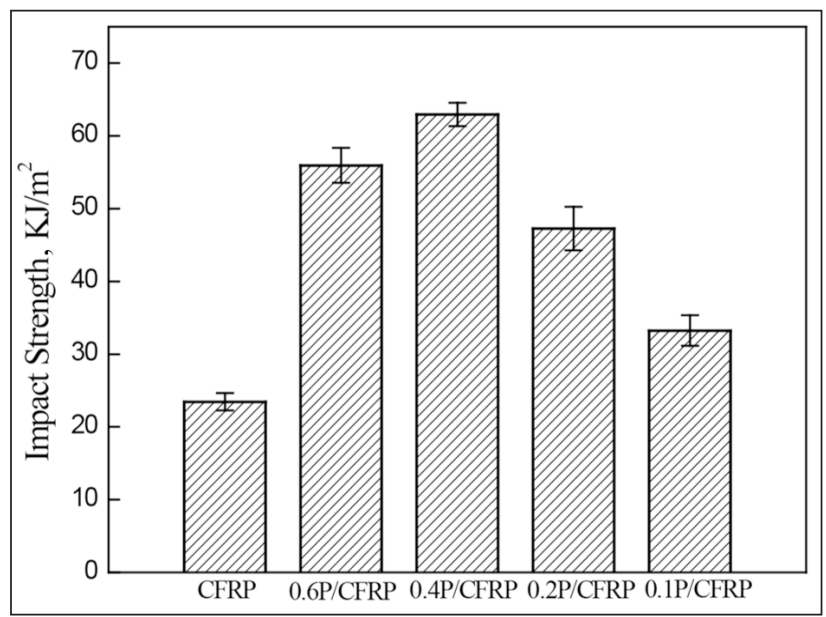

Fig. 3. Effect of diameter on the impact strength

As for the failure mechanism and energy absorption characteristics of the cantilever beam impact test, the failure of the laminate occurs in two steps during impact. First, deformation takes place due to compressive force and shear. This is followed by the formation of interlayer fractures and the eventual failure of the material. Compared with its tensile properties, carbon fibre has relatively poor compression and shear properties, which is also the reason for the low impact resistance and toughness of reinforced carbon fibre composites. In this study, part of the impact energy due to compression and shear of the carbon fibre is transformed into the tensile strain energy of the PET fibre. Therefore, the impact strength of the fibre-wrapped reinforced composites is higher than that of the pure carbon fibre composites. Impact resistance also increases with increasing fibre diameter.

On the other hand, the lower surface energy of the PET fibre results in its relatively poor interfacial adhesion with epoxy resin. As the diameter of the PET fibre increases, its contact area with the resin increases, thus lowering its interlayer or inter-bundle fracture energy. Therefore, the impact strength for a fibre diameter of $0.6 \mathrm{~mm}$ is lower than that for a diameter of $0.4 \mathrm{~mm}$. In summary, a PET fibre with a diameter of $0.4 \mathrm{~mm}$ gives the composite material the best overall impact strength, which represents a $147 \%$ increase compared with unwrapped carbon fibre composites.

Figure 4 shows the effects of fibre diameter on the tensile strength of the material. As can be seen from the figure, wrapping with polyester fibre contributes little to the tensile strength of the composites. Moreover, the performance of the composites decreases with increasing polyester fibre diameter. There are two reasons for this, the poor interfacial bonding between the PET fibre and the epoxy resin, and the buckling of the carbon fibre as PET wraps around and coats it.

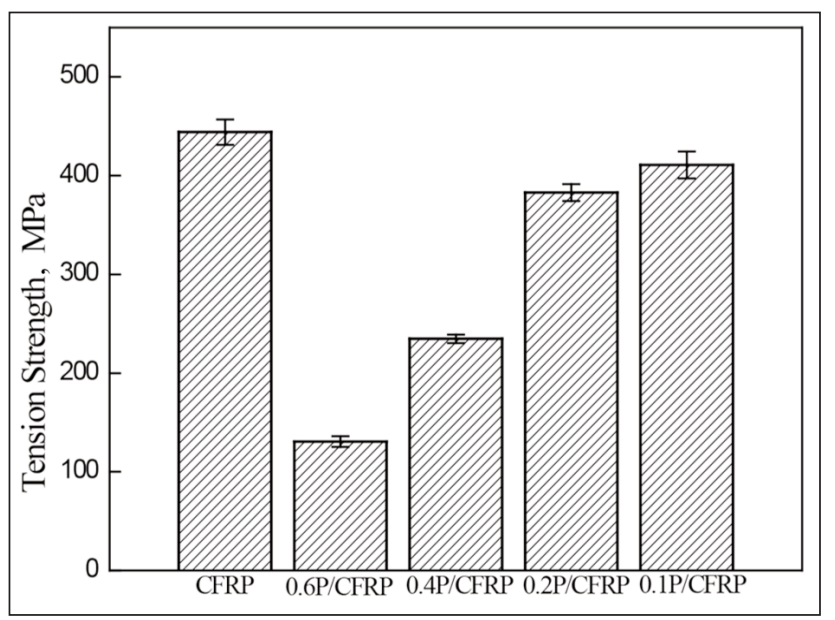

Fig. 4. Effect of diameter on the tensile strength

The hardness of the polyester fibre also increases with increasing diameter, making it less deformable during wrapping. The carbon fibre is thus more prone to buckling, the degree of which has a great influence on the tensile strength of this composite material. The phenomenon was depicted in figure 5. From our 


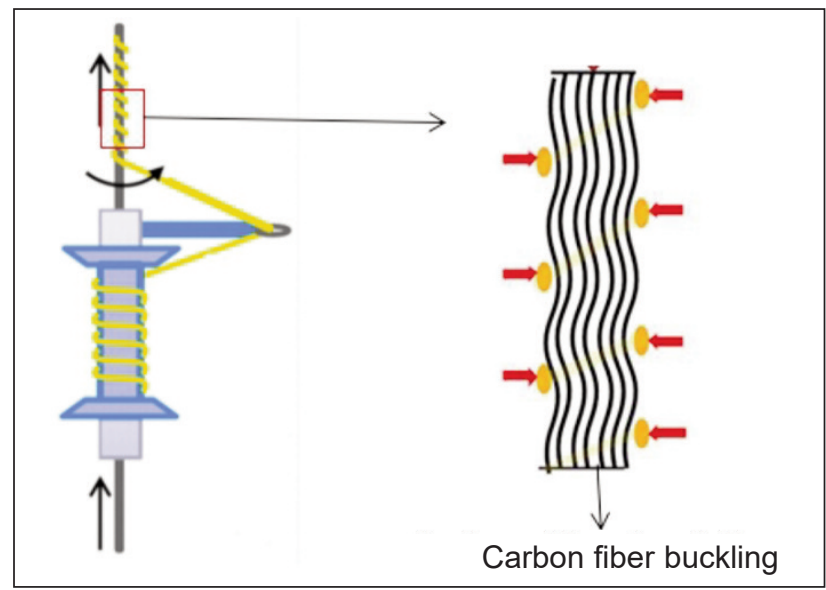

Fig. 5. Schematic diagram of carbon fibres buckling in the wrap process

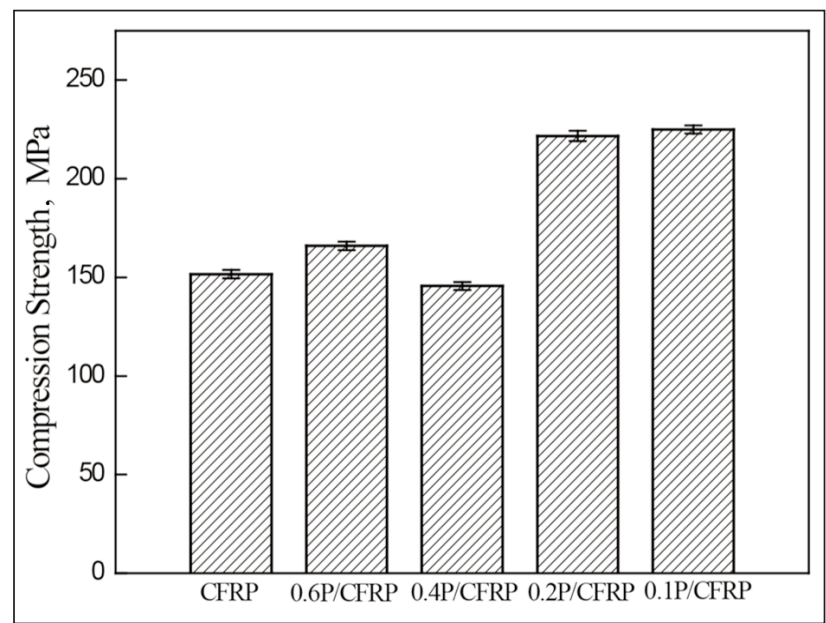

Fig. 6. Effect of diameter on the compressive strength

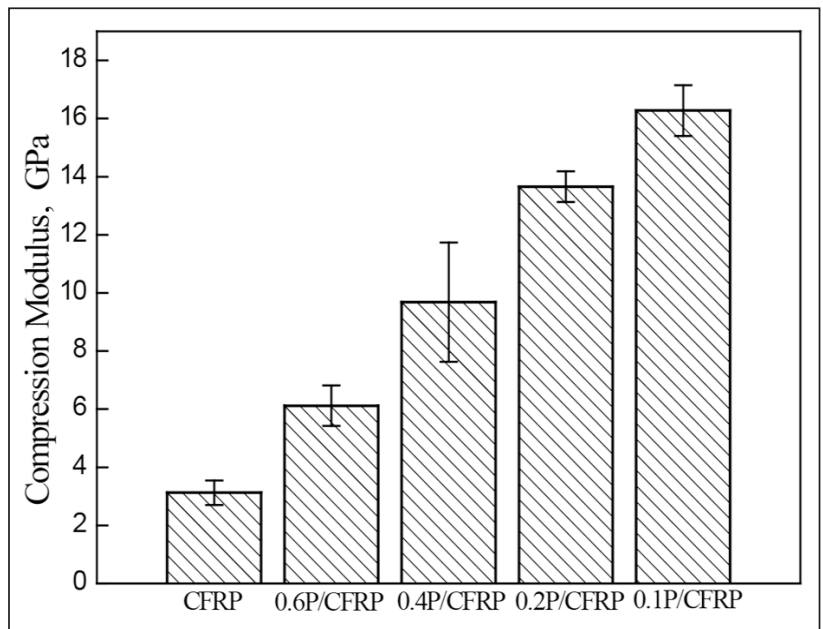

Fig. 7. Effect of diameter on the composite modulus

experimental results, we determined that the buckling of the carbon fibre bundle becomes more severe when wrapped with polyester fibre with a larger diameter. It is, therefore, necessary to optimize the diameter of the wrapping fibre for the wrapping process. Figures 6 and 7 show the compressive strength and modulus of the composite material. From these data, we concluded that fibre wrapping improves the compressive strength and modulus of the composite material. Reducing the fibre diameter results in a gradual increase in the performance of the composite material during compression because the fibre wrapping functions differently than during stretching. Part of the compressive and shear energy on the carbon fibre is converted into the tensile strain energy of the PET fibre, as in the case of impact, thus increasing the compressive strength of the carbon fibre. As shown in the SEM image of figure 8 , the compression failure of the wrapped composite material adopts the form of a torsional failure, which is similar to a shear failure, rather than the buckling failure of the fibre, such that brittle fracture is observed during the failure of the carbon fibre within the resin wrapping. The PET wrapping, therefore, alters the compression failure mode of the composite material and improves its performance during compression. Using a thinner PET fibre is more effective for enhancing this property of the composite material.

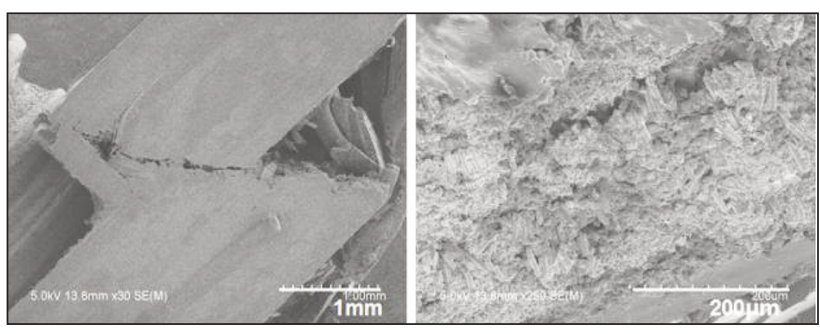

Fig. 8. Morphologies of the fracture surface of $0.2 P / C F R P$

\section{CONCLUSIONS}

With the data analysis in the above sections, the effects of diameter on the impact behaviour of WHC composites can be summarized as follows:

Polyester fibre wrapping improves the impact strength of the composites, which increases and then decreases as the diameter of the polyester fibre increases. The maximum impact strength of 62 $\mathrm{KJ} / \mathrm{m}^{2}$ was reached when the polyester fibre diameter was $0.4 \mathrm{~mm}$, representing a $147 \%$ enhancement compared with the unwrapped material.

Wrapping with polyester harms the tensile properties of the composites because buckling of the carbon fibre can happen during wrapping, the degree of which has a great influence on the tensile strength of the composites. Moreover, the polyester fibre does not play a significant role in preventing tensile failure, and thus the tensile strength of the material drops.

Though the polyester fibre wrapping causes different degrees of buckling on the carbon fibre bundles, overall it improves the performance of the composite material during compression. Thinner wrapping fibres are more effective for enhancing the compression property of the composites. The fracture mode of the material during compression failure is also changed by wrapping with fibre. The failure of the carbon fibre adopts the form of a torsional failure, similar to shear failure. 
The diameter of the polyester fibre used for wrapping should be optimized as per the application of the composite material.

Fibres with higher tensile strengths provide better impact resistance, while thinner wrapping fibres enhance the compression properties of the composite material more effectively.

\section{ACKNOWLEDGEMENTS}

This work has been financially supported by the Open Project Program of Anhui Province College Key Laboratory of Textile Fabrics, Anhui Engineering and Technology Research Center of Textile (2018AKLTF05), Anhui Province International Science and Technology Cooperation Program (1804b06020360), as well as Science and Technology Planning Project of Wuhu City (No. 2018yf47).

\title{
REFERENCES
}

[1] Li, W., Guo, Q.F., Application of carbon fiber composites to cosmonautic fields, In: Chinese Journal of Optics, 2011, 4, 3, 201-212

[2] Qian, D., Bao, L., Takatera, M., et al., Fiber-reinforced polymer composite materials with high specific strength and excellent solid particle erosion resistance, In: Wear, 2010, 268, 3, 637-642

[3] Bunsell, A.R., Renard, J., Fundamentals of Fibre Reinforced Composite Materials, In: B. Cantor, M. J. Goringe (Eds), Institute of Physics Publishing: Bristol and Philadelphia, 2005, Ch.1., 1-17

[4] Gillespie, J.W., DeVault, J.B., High-Performance Structural Fibers for Advanced Polymer Matrix Composites, In: A. Mozhi (Eds), The National Academies Press: Washington, DC, 2005, 18-26

[5] Nur, S., Safri, A., Thariq, M., et al., Impact Behaviour of Hybrid Composites for Structural Applications: A Review, In: Compo Part B, 2018, 112-121

[6] Senthilkumaar, S., Varadarajan, P.R., Porkodi, K., Subbhuraam, C.V., Adsorption of methylene blue onto jute fiber carbon: kinetics and equilibrium studies, In: Journal of colloid and interface science, 2005, 284, 1, 78-82

[7] Hung, P.Y, Lau, K.T, Cheng, L.K, et al., Impact response of hybrid carbon/glass fiber reinforced polymer composites designed for engineering applications. In: Compo Part B, 2018, 86-96

[8] Zheng, Y., Sun, Y., Li, J., et al., Tensile response of carbon-aramid hybrid 3D braided composites, In: Mater Design, 2017, 246-252

[9] Liu, B., Xu, A., Bao, L., Erosion characteristics and mechanical behavior of new structural hybrid fabric reinforced polyetherimide composites, In: Wear, 2016, 368, 335-343

[10] Ruan, F, Bao, L., Improved longitudinal compression performance of a unidirectional fiber reinforced composite with a filament covering, In: Polym Compo, 2016, 37, 11, 3127-3133

\author{
Authors: \\ FANGTAO RUAN ${ }^{1,2}$, CHENGLONG XIA ${ }^{1}$, LI YANG ${ }^{1,2}$, ZHENZHEN XU ${ }^{1,2}$, \\ FEIYAN TAO ${ }^{1}$ \\ ${ }^{1}$ Anhui Polytechnic University, School of Textile and Garment, 241000, Wuhu, China \\ 2International Cooperation Research Center of Textile Structure Composite Materials, \\ 241000, An Hui Province, China \\ Corresponding author: \\ FANGTAO RUAN \\ e-mail: ruanfangtao@ahpu.edu.cn
}

